\title{
The Nexus between Macro-Prudential Banking Regulation, Interest Rate Spread and Monetary Policy in South Africa
}

\author{
Shayanewako Varaidzo Batsirai ${ }^{\dagger}$, Asrat Tsegaye, Yohane Khamfula \\ University of Fort Hare, South Africa \\ †vbshayanewako@live.co.za
}

\begin{abstract}
This study is an empirical attempt to investigate the nexus between macro-prudential banking regulation, interest rate spread and monetary policy in South Africa. The effectiveness of monetary policy and alarmingly wide interest rate spread has been a contentious issue in the corridors of central banks across the globe in this lifetime. This has been largely because monetary policy alone proved to be less efficient in mitigating the effects of systemic risk, particularly during the 2007 financial crisis, necessitating the need for macro-prudential banking regulation. Time series dataset spanning from 1994Q1 to 2016Q4 is employed to carry out this study using the restricted Vector Autoregressive (VAR) model, that is, the Vector Error Correctional Model (VECM). The results show that there is no long-run causality running from trade openness, real exchange rate financial depth interest rate spread and credit growth to the repo rate in South Africa. A short run causality running from credit growth to the repo rate exists from the estimated model. In addition, the empirical results exhibited evidence that interest rate spread has a dampening effect on monetary policy but in the long-run this effect seems reversible in South Africa. Therefore, in order to ensure financial stability, care has to be taken by the South African Reserve Bank and government in choosing the best tool-kit of macro-prudential banking regulation as it can be used to disguise the symptoms of a lax monetary policy framework.
\end{abstract}

Keywords: Macro-prudential banking regulation; Interest rate spread; Monetary policy; New Keynesian Dynamic Stochastic General Equilibrium Model; Financial stability.

\section{Introduction}

The inflation targeting framework was adopted as the flagship of monetary policy in South Africa since the year 2000. It has been a policy that has long been used as the anchor of monetary policy under the jurisdiction of the South African Reserve Bank (SARB). The general target of inflation in South Africa is a range between 3\% and 6\% (SARB, Annual Report, 2015). In order to keep the rate of inflation within the desired range, the SARB uses the repo rate as a policy tool. However, the annual rate of inflation in South Africa has evolved above the targeted range since early 2007 (SARB, Annual Report, 2015). This has been partly due to the persistent increase of the repo rate in order to bring down the rate of inflation, thereby accelerating its trend rather than subduing it. Accordingly, various views, policies and a menu of strategy objectives arose in the wake of the recent global financial maelstrom as to how financial stability can be sustained in the face of economic shocks across the globe. Nonetheless, the use of monetary policy to attain financial stability has proven to be an insufficient condition on its own (Vanhoose, 2007). In addressing certain financial vulnerabilities, for instance, excessive leverage and maturity transformation, the effectiveness of monetary policy is less direct compared to regulatory or supervisory interventions.

These interventions, commonly known as macro-prudential banking regulation, according to Van Roy (2005), refer to policies that emphasise the use of prudential instruments to mitigate systemic risk across the financial market. In other words, Adrian, Fleming, Shachar and Vogt (2015) define it as a framework that improves the lines of defence against financial instability or vulnerability. The deleterious after-effects of the 2007 financial crisis clearly indicated the weaknesses of the micro-prudential regulation and monetary policies in mitigating systemic risk. It is no surprise, therefore, that the SARB openly acknowledges the association between macro-prudential banking regulation and monetary policy (SARB, Annual report, 2016). The need to carry out this study has been stirred by the fact that much of the empirical literature pertaining to prudential and supervisory oversight of financial institutions is found in advanced economies ( (MAG, 2015); Were and Wambua (2014), (Woodford, 2012); Adrian, Fleming, Shachar and Vogt (2015)). The prominent of these studies used Bayesian estimation techniques and the Generalized Method of Moments (GMM), and their findings cannot be divorced from the relationship between minimum capital requirements and financial stability. Empirical studies in South Africa mainly focused on the effects of minimum capital 
requirements on banking efficiency and productivity (Havemann, 2014); Tabak and Souto, 2010). It follows therefore that there is a need to empirically investigate the relationship between macro-prudential banking regulation, interest rate spread and monetary policy in the context of South Africa.

This is important for three main reasons. For one, knowledge on the nexus between macro-prudential regulation, interest rate spread and monetary policy enables policymakers and the government to select and implement the correct prudential and monetary policy tool-kits that are aimed at strengthening the financial system and the general growth of the economy. In addition, this particular study will provide monetary authorities with empirical evidence in order to come up with precise and targeted policy measures as to when the monetary policy or macro-prudential regulation need to be tightened or contracted for any given various economic shocks. Thirdly, this study is of importance because the adoption of the inflation targeting in South Africa has never been empirically tested with current data to determine the nexus between macroprudential policy, interest rate spread and monetary policy in South Africa.

Overview of Banking, Interest Rate Spread and Monetary Policy in South Africa: The structure of the South African banking sector is exhibited in Figure 1. Kganyago (2016) maintains that South Africa has a world-class banking system because of its compliance with the international banking regulation standards. The South African banking sector comprises 15 branches of foreign banks; 36 foreign bank representatives; 6 foreign-controlled banks; 10 locally controlled banks, and 3 mutual banks (SARB, 2016).

\section{Figure 1: South African Registered Banks and Representative Offices}

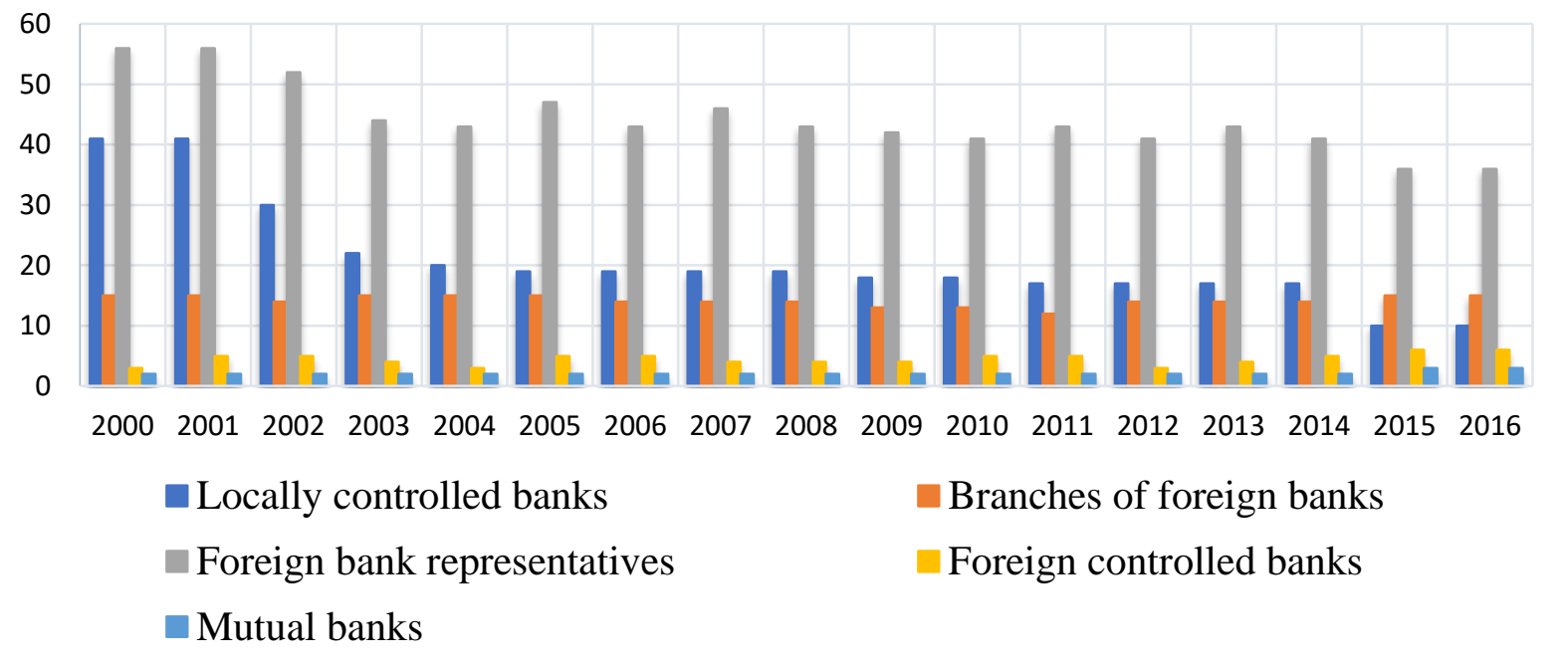

Source: SARB Annual Report (2015) and SARB Annual Report (2016)

The trends in credit growth for the South African banks are exhibited in Figure 2. Credit growth, as will be indicated in the methodology section, is used in this study as a proxy of macro-prudential banking regulation. Figure 2 clearly shows that credit growth swiftly dropped soon after the 2007-2009 financial crises. This could be attributed to the deepening of the banking regulation standards by the SARB, and the adoption of an accommodative monetary policy framework. The general growth in all the credit advanced to households averaged about 4\% during 2014 and 2015. During the end of 2015 to the first quarter of 2016, the total lending to households has been negative in its real terms (SARB, 2016). 
Figure 2: Trends in Credit Growth of the Banking Sector in South Africa

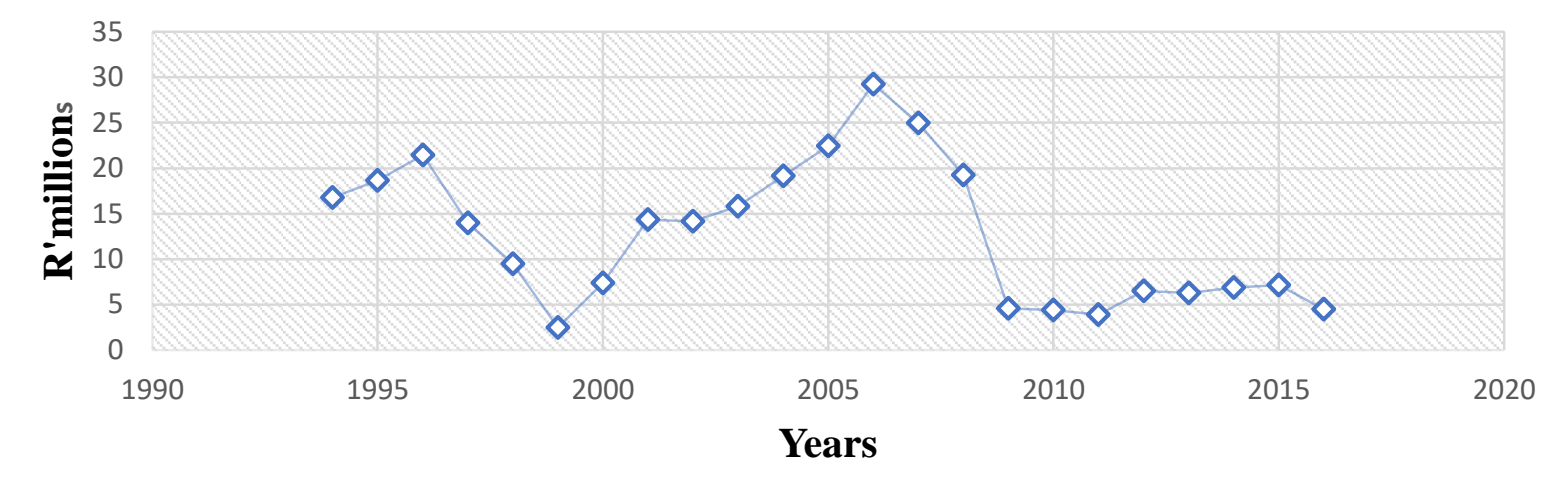

Source: SARB (2016)

The trends in the lending and deposits rates are exhibited in Figure 3, and the difference between these two rates is the interest rate spread. It can be seen from Figure 3 that the deposit and lending rates follow the same pattern, with lending rates fluctuating above the deposit rates. The lending rate in South Africa has remained unchanged during 2016, at about $10 \%$ from an average of $9 \%$ in 2014 . The lending rates averaged 12\% from 1994 until 2017, reaching an all-time high of 26\% in August 1998 and a record low of 5\% during the apartheid era in September 1990 (Kganyago, 2016).

Figure 3: Lending and Deposit Rates in South Africa 1994/Q1-2016/Q4

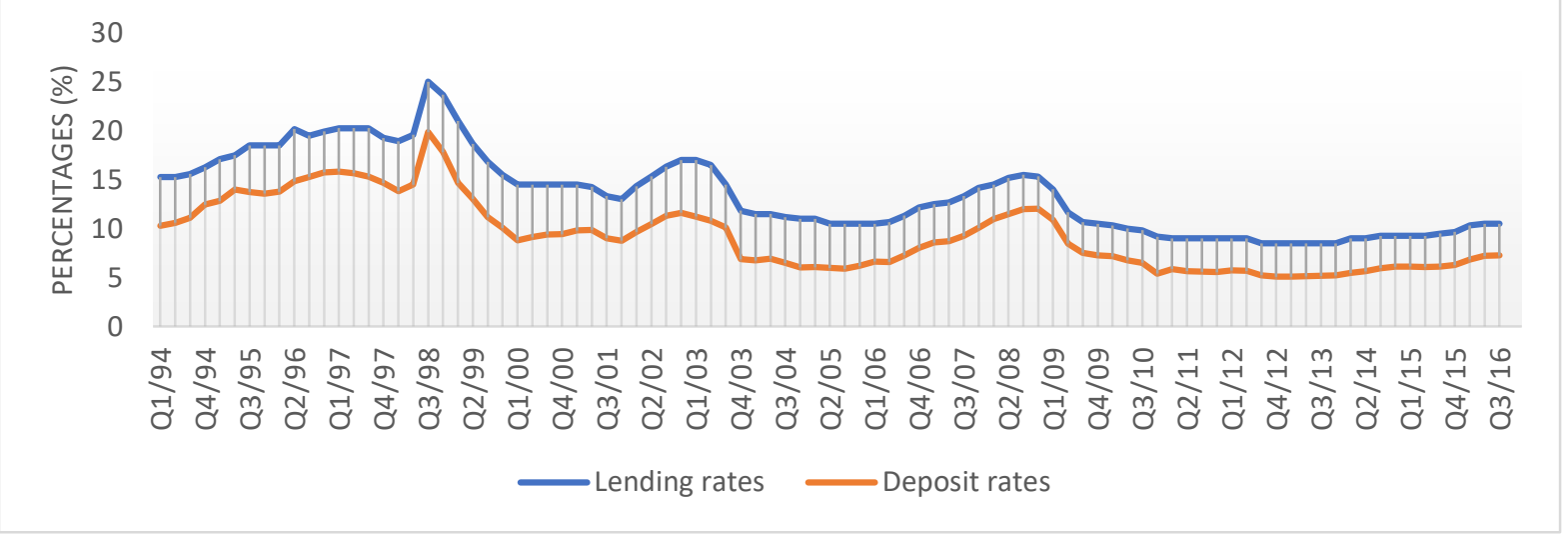

Source: SARB (2016)

The trends in the South African repo rate and the inflation rate are depicted in Figure 4. Before the adoption of the formal inflation targeting in South Africa, inflation averaged 10\%, which has declined to an average of $6 \%$ during the formal inflation targeting period (SARB, 2016). In addition, the average nominal policy rate slumped from $16 \%$ to $9 \%$ as the average real policy rate plummeted from $6 \%$ to an average of $3 \%$ since the year 2000 (Mboweni, 2010). A closer look on the economic trends in South Africa from 2010 indicate that the inflation rate has averaged 5\%, real growth in GDP at about 3\%, the repo rate $5.5 \%$ and the real repo rate at an average of $0.3 \%$ (SARB, 2016). It is interesting to note that the volatility in the trends of these variables is much lower in the formal inflation targeting period as compared to the period before the adoption of the formal inflation targeting in South Africa. The trends presented in Figure 4 shows that interest rates were sharply decreased to 6\% between 2007 and 2009, with the inflation rate plummeting above $11 \%$ in 2009 . The short-term interest rates were hiked by $0.5 \%$ during 2015 , in anticipation that the inflation rate will remain above the maximum target of $6 \%$ (SARB, 2016). This was a cumulative increase of about $2 \%$ since the first quarter of 2014. The consumer price index (CPI) averaged 9\% between 1994 and 2016, reaching a record low of $0.20 \%$ in the second quarter of 2004 . 


\section{Figure 4: The Repo Rate and Inflation Rate in South Africa}

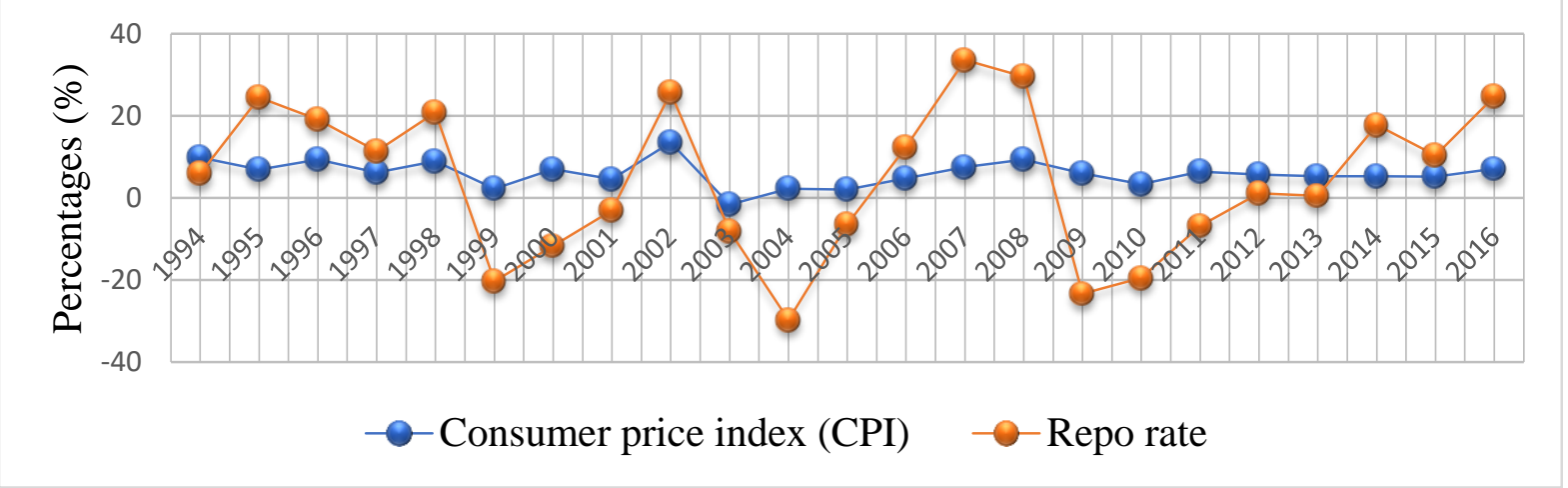

Source: EIU (2016) and Quantec data

The rest of the paper is structured as follows: Section 2 deals succinctly with the literature review of the study. Section 3 presents the methodology employed in this paper. The results and discussion of findings are presented in section 4. Lastly, section 5 converses the conclusion and policy implications of the study.

\section{Literature Review}

The concept of macro-prudential banking regulation is founded within the traditional banking theory which is strongly built on the tenets that systemic risk is a major ingredient of financial instability. This theory, like the efficient market theory by Keynes, proposes that financial vulnerabilities, such as the 2007 financial meltdown, signifies inefficiency in policies to mitigate the effects of systemic risk (Meh \& Moran, 2010). At the heart of the concept of systemic risk is the hypothesis of the inherent instability of financial systems (Vanhoose, 2007). When the financial system is unstable, the transmission mechanisms of monetary policy become ineffective and the inefficient intermediation functioning of financial institutions become a common phenomenon. Therefore, in order to ensure stability across the financial system, a number of studies have been undertaken to investigate the need for prudential regulation and oversight. One of the major studies in this area was undertaken by Macroeconomic Assessment Group (MAG) (2015), which used the Bayesian estimation techniques in the Arab region, and found that an increase in capital adequacy ratios of $1 \%$ point increases lending spreads by about 15 basis points, but this depends crucially on how banks can adjust their profitability.

Another study was conducted by Woodford (2012) in Spain to establish the correlation between macroprudential regulation and the banking system soundness. It was found that capital adequacy requirements are asymmetric with an average of about $0.5 \%$ decrease in capital-to-assets ratio inducing about $1.6 \%$ increase in interest rates. However, they also concluded that a sudden increase of $1.5 \%$ in capital-to-assets ratio translates to an expansionary move of the monetary policy. Bebchuk and Goldstein (2011) estimated the effects of the Basel III minimum capital requirements on economic growth of the three main Organizations for Economic Cooperation and Development (OECD) economies, that is, Japan, USA, and the Euro area. It was found that a $1 \%$ rise in the ratio of capital to risk-weighted assets expanded interest rate spreads by about 14.4 basis points on average in these economies. It was further found that to conform to the new Basel III standards banks have to averagely increase their lending spreads by 15 and 50 basis points. The Basel III principles were found to drop the output growth rate by about $0.23 \%$ subsequent to 5 years of implementation translating to an average annual decline of the output growth rate of $0.05 \%$.

Analogous results were confirmed by the MAG (2015) in their study of the effects of bank capital ratios in member countries. It was found that a $1 \%$ increase in the ratio of common equity to risk-weighted assets would bring about an increase in interest rate spreads of about 15.5 basis points. This was estimated to increase till the 35th quarter since the execution of the Basel III requirements and show signs of waning from then on. This was as a result of a 1.4\% decrease in the lending capacity of banks. In another study by Havemann (2014) investigating the counter-cyclical capital buffers and interest rate policy as compliments in South Africa, it was found that a 1\%-point shock to capital adequacy ratio has similar effects to an interest 
rate shock of between 0.3 and 0.4 percentage points. This study extended the standard large-scale macroeconomic model to include capital adequacy ratio as a policy lever. Similarly, Havrylchyk (2010) developed a macroeconomic credit risk model for stress testing the South African banking sector and it was found that macroeconomic shocks exert an average of $0.5 \%$ to $0.8 \%$ credit losses on the banking sector.

\section{Methodology}

The New Keynesian Dynamic Stochastic General Equilibrium Model (NKDSGEM) underpins the theoretical foundations of this study. Peersman and Straub (2006) maintain that the NKDSGE economic model is made up of four agents, namely, households, firms, the government and a monetary policy authority (the South African Reserve Bank). The representative household has the following budget constraint:

$$
\frac{\beta_{t-1}+W_{t} l_{t}+D_{t}}{P_{t}} \geq c_{t}+\frac{\frac{\beta_{t}}{r_{t}}}{P_{t}}
$$

Where, $W_{t} l_{t}$ represents nominal factor payments received by households after supplying some quantity of labour, $l_{t} i$, at a nominal wage rate of $W_{t} \cdot \frac{B_{t}}{r_{t}}$ denotes the nominal price of new bonds and $P_{t}$ represents the prices of goods and services. The notation $D_{t}$ is a measure of the dividends that are paid to households. To prevent the households from excessive borrowing, we impose the No-Ponzi-game restriction, and the expected utility maximisation function of the representative household will take the form:

$$
\mathrm{E} \sum_{t=0}^{\infty} \beta^{t}\left(\frac{c_{t}^{1-\delta}}{1-\delta}-\mathrm{x}_{t}^{1_{t}^{1+\eta}} \frac{1+\eta}{1+\eta}\right)
$$

The subscript, $0<\beta<1$, captures the discount factor and $x>0$ is a measure of the relative weight of the labour disutility the inverse of the elasticity of intertemporal substitution of consumption is denoted by the parameter $\delta \geq 0$. The Frisch labour supply elasticity is measured by $\eta \geq 0$. In order to decipher the optimisation problem of the representative household, the following Langrangian is formed:

$\max _{c_{t}, l_{t, \beta_{t}}} A=\mathrm{E} \sum_{t=0}^{\infty}\left[\beta^{t}\left(\frac{c_{t}^{1-\delta}}{1-\delta}-\mathrm{x}_{t}^{l_{t}^{1+\eta}}\right)-\beta^{t} \lambda_{t}\left(C_{t}+\frac{\frac{\beta_{t}}{r_{t}}}{P_{t}}-\frac{\beta_{t-1}}{P_{t}}-\frac{W_{t} l_{t}}{P_{t}}-\frac{D_{t}}{P_{t}}\right)\right]$

The second agent in the NKDSGEM is the firms or businesses with an aggregate price level $\left(P_{t}\right)$ of the form:

$$
P_{t}=\left[\theta P_{t-1}^{1-\varepsilon}+(1-\theta)\left(P_{t}^{*}\right)^{1-\varepsilon}\right] \frac{1}{1-\varepsilon^{\prime}}
$$

The third agent is the government that exhibit the following budget identity:

$$
P_{t} G_{t}+\beta_{t}-1=\frac{\beta_{t}}{R_{t}}-T_{t}+M_{t} M_{t-1}
$$

Where, $G_{t}$ represents the consumption of the government of final goods that are financed by lump sum taxes and borrowing denoted by $T_{t}$, and the government issues bonds that are domestically held, these are represented by $M_{t}$. Lastly, the interest rate target is defined by means of a simple monetary policy rule that depends on inflation and the output gap as follows:

$$
\frac{R_{t}}{R}=\left(\frac{\pi_{t}}{\pi}\right) \tau \pi\left(\frac{Y_{t}^{g a p}}{Y^{g a p}}\right)^{\mathrm{\tau y}} v_{\mathrm{t}}
$$

Where, $\pi_{t}=\frac{P_{t}}{P_{t-1}}$, represent the gross inflation rate between period $t-1$ and $t$, and $Y_{t}^{\text {gap }}$ denotes the output gap. The monetary policy shock $v_{t}$, captures the unsystematic components of the interest rate policy. The primary assumption of this model is that all agents in the economy are assumed to be conversant with this interest rate rule and the central bank supplies money stock to the extent that is demanded by households at the existing nominal interest rate, income and prices. The summation of formulation (the 3), (4), (5) and (6) gives the standard NKDSGE model.

Model Specification: Guided by the NKDSGE model discussed above, this study develops and extends upon the econometric model of Peersman and Straub (2006). Therefore, the model to be estimated takes the following form:

$$
\log R P R R_{t}=\alpha_{0}+\beta_{1} \log F D E P_{t}+\beta_{2} \log T O P N_{t}+\beta_{3} \log I R S_{t}+\beta_{4} \log R E X R_{t}+\beta_{5} \log C R G W_{t}+v_{t}
$$

The South African monetary policy is represented by $\log R P R R_{t}, \log F D E P_{t}$ denotes the financial depth, which is calculated as $\frac{M 2}{G D P}$, trade openness $\left(\frac{(\text { exports }+ \text { imports })}{G D P}\right)$ is described by $\log T O P N_{t}, \log I R S_{t}$ represents the 
interest rate spread (lending rates - deposit rates), the South African real effective exchange rate is denoted by $\log R E X R_{t}$ and credit growth (a proxy of macro-prudential banking regulation) is represented by $\log C R G W_{t}$, and $v_{t}$ depicts the error term. The subscript $\alpha_{0}$ denotes the intercept term, and $\beta_{1}$ to $\beta_{5}$ represents the coefficients of the regressors respectively.

Estimation Techniques: This study is an econometric attempt to establish the nexus between macroprudential banking regulation, interest rate spread and monetary policy using the restricted Vector Autoregressive (VAR) model, that is, the Vector Error Correctional Model (VECM). However, prior to the estimation of the econometric model, the unit root in the series was analysed using the unit root tests, namely, the Augmented Dickey-Fuller (ADF) and the Generalised Dickey-Fuller (DF-GLS) test proposed by Elliot, Rothernberg, and Stock (1996). In order to carry out this study quarterly time series data extracted from two sources within the Quantec database, namely, the South African Reserve Bank and the Statistics South Africa was employed. The selection of the data period was informed by the interest to investigate the nexus between macro-prudential banking regulation, interest rate spread and monetary policy covering the inflation targeting period and the pre-and post-crisis phases that bruised the South African banking system. The econometric tools used to carry out this study were chosen because the vectors proved to be I(1) in their second difference form and I(0) in levels. To investigate the long run relationship between the variables, the Johansen cointegration technique was employed.

Cointegration Tests and the VECM: If the variables are found to be non-stationary and integrated of the same order, then the Johansen (1995) and Johansen and Juselius (1995) cointegration test will be performed to determine the long-run association ship between the variables. The pre-condition of the VECM methodology is that the data should become stationary after first difference and it should be integrated of the same order (Clemente, Montanes and Reyes, 1998). If the data series satisfy this pre-condition then the restricted VAR, namely the VECM (otherwise the unrestricted VAR will be run) and other econometric tests such as the Wald test, diagnostic checks, residual tests and the test of normality in the residuals will be performed.

\section{Results and Discussion}

In order to give proper treatment to time series data, the variables must be non-stationary in levels. The most econometric applications will be possible if all the variables become stationary after they are converted into first difference (Gujarati, 2004). According to the results depicted in Table 1, all of the ADF statistics become integrated of the same order after the first difference. Similarly, the DF-GLS test results of unit root, as shown in Table 1, shows that all the other variables become stationary or integrated of the same order after being first differenced.

Table 1: Unit Root Results

\begin{tabular}{lllllll}
\multicolumn{2}{c}{ ADF Unit Root Test } & \multicolumn{5}{c}{ DF-GLS Test } \\
\hline Variable & $\begin{array}{l}\text { Statistics } \\
\text { in levels }\end{array}$ & $\begin{array}{l}\text { Statistics in } \\
\text { difference }\end{array}$ & $\begin{array}{l}\text { Order } \\
\text { integration }\end{array}$ & $\begin{array}{l}\text { Statistics } \\
\text { in levels }\end{array}$ & $\begin{array}{l}\text { Statistics in 1 } \\
\text { difference }\end{array}$ & $\begin{array}{l}\text { Order } \\
\text { integration }\end{array}$ \\
\hline CRGW & -2.98 & $-2.475^{* *}$ & $1(1)$ & -1.623 & $-2.592^{* * *}$ & $1(1)$ \\
RPRR & -1.345 & -3.876 & $1(1)$ & -2.306 & -6.283 & $1(1)$ \\
IRS & $-4.901^{*}$ & -5.243 & $1(1)$ & $-5.298^{*}$ & -5.298 & $1(1)$ \\
FDEP & -1.98 & -9.922 & $1(1)$ & -1.683 & -3655 & $1(1)$ \\
TOPN & -2.322 & -13.771 & $1(1)$ & -2.031 & $-2.564^{* *}$ & $1(1)$ \\
\hline
\end{tabular}

$* / * * /{ }^{* * *}$ denotes rejection of $\mathrm{H}_{0} @ 10 \% / 5 \% / 1 \%$ level of significance respectively

Source: Author's computation using E-views 9 Econometric Software

Cointegration Test Results: The vectors in the model have met the preconditions of the Johansen test of cointegration, namely, non-stationarity of variables in levels or integrated of the same order after first difference. Therefore, we proceed with the testing of the existence of any long-run relationship between the vectors using the Johansen test of cointegration. The test results of the Johansen cointegration are shown in Table 2(a) and 2(b). This study applied the unrestricted cointegration rank test (Trace) and the Maximum Eigenvalue rank test of cointegration to test the long-run relationship between the vectors. 
Table 2(a): Unrestricted Cointegration Rank Test (Trace)

\begin{tabular}{lllll}
\hline $\begin{array}{l}\text { Hypothesized } \\
\text { No. of CE(s) }\end{array}$ & Eigenvalue & Trace Statistic & $\mathbf{0 . 0 5}$ Critical Value & Prob.** \\
\hline None* $^{*}$ & & & & 0.0000 \\
At most $1^{*}$ & 0.509377 & 169.9344 & 95.75366 & 0.0000 \\
At most 2* & 0.405674 & 107.2715 & 69.81889 & 0.0016 \\
At most 3 & 0.313563 & 61.48264 & 47.85613 & 0.0723 \\
At most 4 & 0.174623 & 28.37350 & 29.97907 & 0.1834 \\
At most 5 & 0.099534 & 11.48497 & 15.49471 & 0.1329 \\
\hline
\end{tabular}

Trace test indicates 3 cointegrating eqn(s) at the 0.05 level; * denotes rejection of the hypothesis at the 0.05 level; **MacKinnon-Haug-Michelis (1999) p-values

Table 2(b): Unrestricted Cointegration Rank Test (Maximum Eigenvalue)

\begin{tabular}{lllll}
\hline $\begin{array}{l}\text { Hypothesized } \\
\text { No. of CE(s) }\end{array}$ & Eigenvalue & Max-Eigen Statistic & $\mathbf{0 . 0 5}$ Critical Value & Prob.** \\
\hline None* & & & & \\
At most $1^{*}$ & 0.509377 & 62.66292 & 40.07757 & 0.0000 \\
At most 2* & 0.405674 & 45.78881 & 33.87687 & 0.0012 \\
At most 3 & 0.313563 & 33.10914 & 27.58434 & 0.0088 \\
At most 4 & 0.174623 & 16.88852 & 21.13162 & 0.1773 \\
At most 5 & 0.099534 & 9.226125 & 14.26460 & 0.2678 \\
\hline
\end{tabular}

Max-eigenvalue test indicates 3 cointegrating eqn(s) at the 0.05 level; ${ }^{*}$ denotes rejection of the hypothesis at the 0.05 level; **MacKinnon-Haug-Michelis (1999) p-values

Source: Author's computation using E-views 9 Econometric Software

The unrestricted cointegration rank test (Trace), as exhibited in Table 2(a), shows 3 cointegrating equations at the 5\% significance level. Deducing from Table 2(a), the p-value of 0.0000 is very small and below $5 \%$ warranting the rejection of the null hypothesis that there are no cointegrating equations in the model. The $\mathrm{p}$ value of $0.16 \%$ is below $5 \%$ meaning that the null hypothesis that there are at most 2 cointegrating equations is rejected hence the hypothesis that there are 3 cointegrating equations at a p-value of $7.23 \%$ accepted. The maximum Eigenvalue cointegration test results also confirm 3 cointegrating equations at the 5\% significance level. According to Table 2(b), the p-value of $17.73 \%$ is above $5 \%$ meaning that the null hypothesis that at most 3 cointegrating equations exist in the model cannot be rejected. The results of the VECM are presented in Table 3.

Table 3: The VECM Results

\begin{tabular}{llll}
\hline Variable & Coefficient & Standard error & T-statistic \\
\hline RPRR & 1.000 & 0.181 & 2.035 \\
TOPN $(-1)$ & -16.670 & 2.631 & -6.336 \\
REXR $(-1)$ & 0.066 & 0.010 & 6.784 \\
FDEP $(-1)$ & -7.396 & 0.910 & -8.127 \\
CRGW $(-1)$ & 4.660 & 1.100 & 4.137 \\
IRS $(-1)$ & 8.897 & 1.472 & 6.044 \\
Constant & 56.802 & 0.281 & 1.036
\end{tabular}

Source: Author's computation using E-views 9 Econometric Software

The Johansen cointegration results have exhibited the existence of cointegrating vectors in the model, thus necessitating the estimation of the restricted VAR, that is, the VECM. The standard econometric analysis practice recommends that the signs of coefficients of variables be reversed when inferring the results under study. The results show that the estimated model has a constant of -56.80 and the repo rate (RPRR) is the dependent variable with a coefficient of 1 . The variable of trade openness (TOPN) and financial depth (FDEP) are positive (16.70) and (7.396) respectively, and their t-statistics are greater than the critical value of 2, thus, there exists a long-run positive relationship between trade openness, financial depth and the repo rate in South Africa. These results concur with the findings of Woodford (2012) who later concluded that an increase 
of $1.5 \%$ in capital-to-assets ratio translates to an expansionary move of the monetary policy. This means that there exists a positive relationship between monetary policy and financial depth in South Africa. A negative long-run relationship exists between the real exchange rate (REXR), credit growth (CRGW) interest rate spread (IRS) and the repo rate.

This is because the coefficients of the real exchange rate $(-0.07)$, credit growth $(-4.66)$ and interest rate spread (-8.90), are negative in sign and their t-statistics, $-6.78,-4.14$ and -6.04 respectively, are all significant. Likewise, Bebchuk and Goldstein (2011) could not refute the evidence that a $1 \%$ rise in the ratio of capital to risk-weighted assets expanded interest rate spread by 14.4 basis points on average in Japan and USA. Their findings pointed to a lower negative relationship between credit growth and the repo rate compared to the $5 \%$ effect credit growth have on the repo rate in South Africa. In addition, the results of the error correction term, in their automatic first difference form, shows that trade openness (coefficient $=-0.193$ and $\mathrm{t}$-statistic $=$ -0.98), indicates that the model will move back to equilibrium at an average speed of $19 \%$. The real exchange rate, financial depth and interest rate spread also indicate that the model will return to equilibrium after an exogenous shock at a speed of about $0.23 \%, 17 \%$ and $121 \%$ respectively. This speed of adjustment is a bit higher than that obtained in previous studies in South Africa, for instance, Havemann (2014) concluded that a 1\%-point shock to capital adequacy ratio has similar effects to an interest rate shock of between 0.3 and 0.4 percentage points.

Nevertheless, the results of the VECM presented in Table 3 do not have probability values to critically analyze the VECM results. To obtain probability values, the systems equation was employed and the results are reported in Table 4. The error correction term or the speed of adjustment towards the equilibrium, according to Table 4, is represented by C (1). If C (1) is negative in sign and significant, then there is a long run causality running from the regressors to the dependent variable. The coefficient of $\mathrm{C}(1)$ is 0.028 and its p-value is $39 \%$, therefore, there is no long-run causality running from the explanatory variables to the regress and because the coefficient and the probability value of $\mathrm{C}(1)$ are non-negative and insignificant respectively. The nonexistence of a long run causality running from, for example, credit growth to the repo rate, was confirmed in the empirical findings of Havrylchyk (2010) who asserted that macroeconomic shocks exert an average of $0.5 \%$ to $0.8 \%$ credit losses on the banking sector. This study further concludes that consideration should be given to the stock of credit that is extended by financial institutions when setting the monetary policy.

Table 4: The Systems Equation of the VECM Test Results

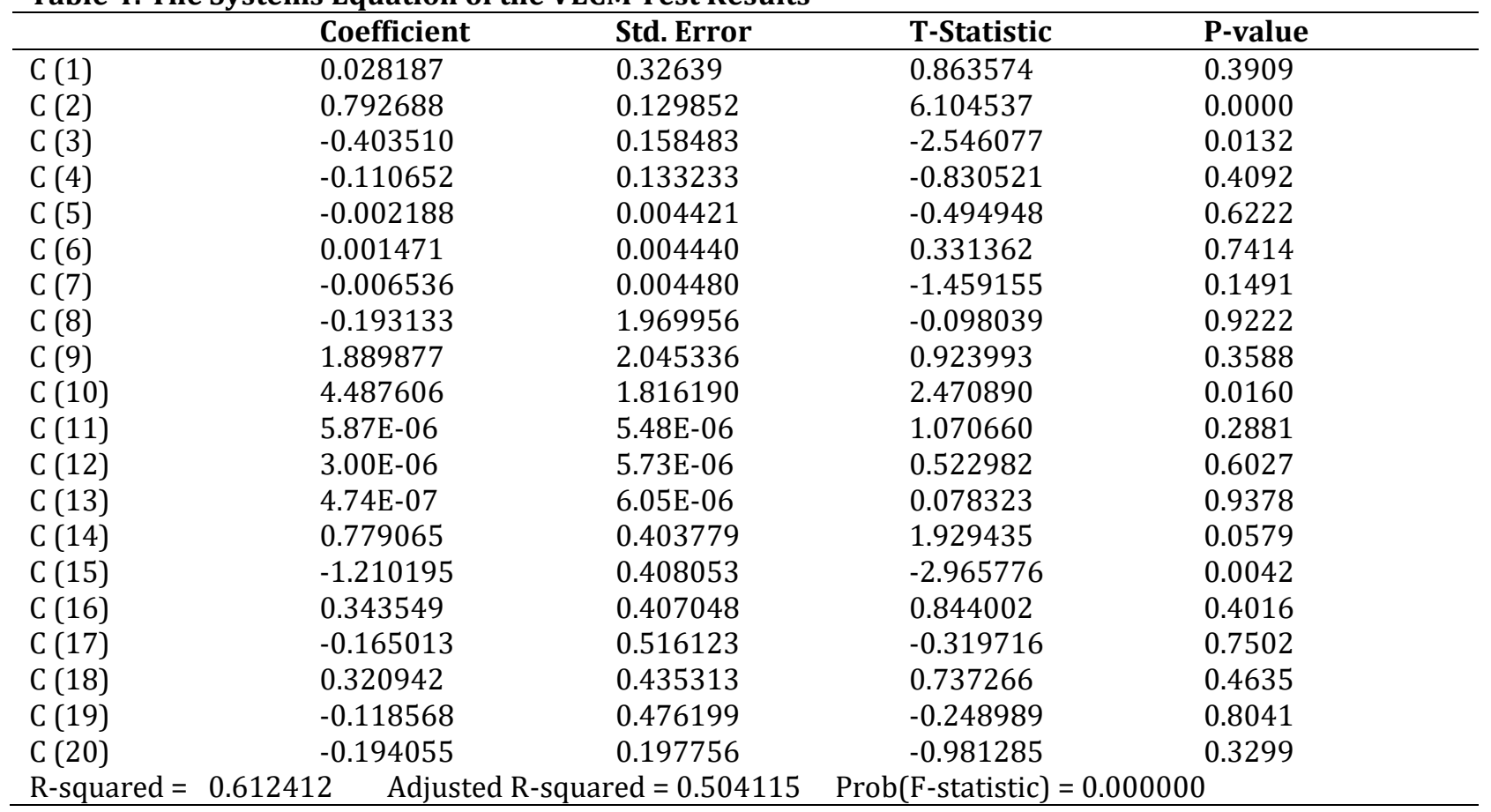

Source: Author's computation using E-views 9 Econometric Software 
Table 5: Analysis of the VECM

\begin{tabular}{|c|c|c|}
\hline Null hypothesis & Test Statistic & Probability \\
\hline \multirow{2}{*}{$C(5)=C(6)=C(7)=0$} & F-statistic & 0.1060 \\
\hline & Chi-square & 0.0956 \\
\hline \multirow[t]{2}{*}{$C(8)=C(9)=C(10)=0$} & F-statistic & 0.4947 \\
\hline & Chi-square & 0.4901 \\
\hline \multirow[t]{2}{*}{$C(11)=C(12)=C(13)=0$} & F-statistic & 0.0000 \\
\hline & Chi-square & 0.0000 \\
\hline \multirow[t]{2}{*}{$C(14)=C(15)=C(16)=0$} & F-statistic & 0.8830 \\
\hline & Chi-square & 0.8834 \\
\hline \multirow[t]{2}{*}{$C(17)=C(18)=C(19)=0$} & F-statistic & 0.5258 \\
\hline & Chi-square & 0.5219 \\
\hline
\end{tabular}

Source: Author's computation using E-views 9 Econometric Software

The null hypotheses, test statistics and probability values for the long run and short run causality analysis of the VECM are presented in Table 5. Using the Wald test, the short run causality running from the independent variable to the dependent variables was carried out. The null hypotheses given in Table 5 have probability values greater than $5 \%$, except for the null hypothesis that $C(11)=C(12)=C(13)=0$. This means that, in exception of the null hypothesis with a probability value less than $5 \%$, we fail to reject all other null hypotheses and it can be concluded that there is no short-run causality running from real exchange rate, trade openness, interest rate and financial depth to the repo rate. The null hypothesis that $\mathrm{C}(11)=\mathrm{C}(12)=\mathrm{C}$ $(13)=0$, with a probability of $0 \%$, which is less than $5 \%$, is rejected and it can be concluded that there is a short run causality running from credit growth to the repo rate.

Diagnostic Test Results: Table 6 shows the diagnostic test results of the estimated model. The $R^{2}(61 \%)$ is greater than $60 \%$, and F-statistic $(0 \%)$ is significant and it can therefore be concluded that the data is fitted well in the model.

\section{Table 6: Diagnostic Test Results}

\begin{tabular}{|c|c|c|c|}
\hline Test & Null hypotheses & Obs- $R^{2}$ & p-values \\
\hline $\begin{array}{ll}\text { Breusch-Godfrey } & \text { Serial } \\
\text { Correlation (LM) } & \end{array}$ & No serial correlation & 4.89 & 18.03 \\
\hline Breusch-Pagan-Godfrey & There is conditional heteroscedasticity & 37.85 & $\begin{array}{l}3.59 \\
0.06\end{array}$ \\
\hline Jarque-Bera (JB) & Residuals are normally distributed & 14.86 & 0.06 \\
\hline
\end{tabular}

Source: Author's computation using E-views 9 Econometric Software

The presence of serial correlation in the model was tested using the Breusch-Godfrey Serial Correlation LM Test. The observed R-squared is 4.89 and the probability Chi-Square using 3 lags is $18.03 \%$. This means that the null hypothesis that there is no serial correlation in the model cannot be rejected rather we accept the null hypothesis. This is good for the model. The Heteroskedasticity test was performed using the BreuschPagan-Godfrey test. The observed R-squared and the probability Chi-square are $37.85 \%$ and $3.59 \%$ respectively. The probability value (3.59\%) is significant and less than a $5 \%$ significance level, therefore, the null hypothesis that there is heteroscedasticity in the residuals is rejected. Rather the alternative hypothesis that there is no heteroscedasticity in the residuals is accepted. This means that the residuals are homoscedastic and this is desirable for the model. The test of normality in the residuals shows Jarque-Bera of 14.86 and a probability value of $0.06 \%$, which is less than $5 \%$. This demonstrates that the null hypothesis that the residuals are normally distributed is rejected, which is not desirable for the model.

\section{Conclusion and Policy Implications of the Study}

In this paper, we have examined the nexus between macro-prudential regulation, interest rate spread and monetary policy in South Africa using quarterly time series data spanning from 1994Q1 to 2016Q4. The results of the unit root tests exhibited that the variables used in this study were I(1) processes. A long-run relationship between the vectors under study was confirmed by the Johansen tests of cointegration. As a 
result, the VECM test was employed. The results of the VECM show that there exists a long-run positive relationship between trade openness, financial depth and the repo rate in South Africa. Moreover, a negative long-run relationship exists between the real exchange rate, credit growth, interest rate spread and the repo rate. In addition, the findings of this study provided strong evidence that the model will move back to equilibrium after an exogenous shock. Using the systems equation to analyse the restricted VAR model, it was found that no long-run causality running from credit growth, interest rate spread and other regressors to the repo rate exists in South Africa. However, the results of this study demonstrated that a short-run causality running from credit growth to the repo rate is present in South Africa. These results concur with the findings of Aikman et al. (2015) who, though with different explanatory variables, confirm a short-run causality running from credit growth to the real interest rate in South Africa. The SARB should carefully monitor the conditions across the credit market in line with its inflation targeting monetary policy rule.

Nonetheless, the endogeneity of credit raises concern in the South African financial sector as interest rates are used to influence credit growth. The findings of this study support the idea that a sound monetary policy must swiftly deal with credit bubbles and equally accommodate the prudential mechanisms in dealing with systemic risk. To achieve this government and monetary authorities must be prepared to encounter the challenge of choosing the most suitable and directed tools of each policy such that the stability of the economy is ensured. This study recommends that caution should be taken on the appropriate selection of measures of macro-prudential regulation and its tool-kit as it can be used to cover for the lax of the current monetary policy in South Africa. The tightening of the monetary policy, usually in the form of risings the repo rate should be motivated by an increase in demand and inflation risks. Conversely, a domestic boom in economic growth and persistent current account surpluses should attract the appreciation of the real exchange rate not necessarily an increase in credit growth. Therefore, this study strongly recommends that the SARB maintain its primary mandate of price stability with some variations targeted at improving the lives of the South Africans. Lastly, the estimation techniques that were used to carry out this study do not constitute a final and definitive work. Further research could be carried out using other techniques to broaden the understanding of the nexus between macro-prudential banking regulation, interest rate spread and monetary policy in South Africa.

\section{References}

Adrian, T. \& Shin, H. S. (2012). Liquidity and leverage. New York: Princeton University.

Adrian, T., Fleming, M., Shachar, O. \& Vogt, E. (2015). Has U.S corporate bond market hit with the crisis? European economics, 60-75.

Aikman, D., Kiley, M. T., Lee, S. J., Palumbo, M. G. \& Warusawitharana, M. N. (2015). Mapping heat in the US financial system. Finance and economics discussion series (pp. 123-140). Washington DC: Federal Reserve System.

Angeloni, I., Faia, E. \& Lo Duca, M. (2015). Monetary policy and risk-taking. Journal of economic dynamics and control, 285-307.

Aron, J. \& Muellbauer, J. (2007). Review of monetary policy in South Africa since 1994. Journal of African economies, 705-744.

BASA. (2016). Contributions to a technical committee to review the spread between the repo rate and the prime rate. Cape town (pp. 87-94). Cape Town: Banking Association of South Africa.

Bebchuk, L. A. \& Goldstein, I. (2011). Self-fulfilling credit market freezes. Review of financial studies, 35193555.

BIS. (2014, June 24). Emerging economies respond to market pressure. Financial crisis effects, pp. 207-283.

Clemente, J. A., Montanes, A. \& Reyes, M. (1998). Testing for a unit root in variables with a double change in the mean. Economics , 59-84.

Dincer, B. \& Eichengreen, W. (2014). Central transparency and independence. International journal of central banking, 189-259.

Disyatat, P. (2011). The bank lending channel revisited. Journal of credit, money and banking, 711-734.

Elliot, G., Rothenberg, T. J. \& Stock, J. H. (1996). Efficient tests for an autoregressive unit root. Econometrica, 813-836.

Greene, W. (2007). Econometric analysis. Upper Saddle River: N.J: Prentice Hall.

Gujarati, D. N. (2004). Basic econometrics. New York: McGraw-Hill. 
Gujarati, D. N. \& Porter, C. D. (2010). Essentials of econometrics. New York: McGraw-Hill.

Havemann, D. W. (2014). The term structure of interest rate spread and economic activity in South Africa. Journal of International Finance, 86-112.

Havrylchyk, O. (2010). Macroeconomic credit risk model for stress testing the South African banking sector. Journal of economics, 65-72.

IMF. (2016). World economic outlook. International Monetary Fund (pp. 161-186). Bank of Canada: Bank of Canada.

Johansen, S. (1995). Likelihood-based inference in cointegrated vector autoregressive models. Oxford: Oxford University Press.

Jorda, O., Schularick, M. \& Taylor, A. M. (2015). Sovereign versus banks, credit, crises, and consequences. New York: McGraw-Hill.

Kashyap, A. K. \& Stein, J. C. (1994). Monetary policy and bank lending. New York: University of Chicago Press.

Kganyago, L. (2016). The impact of the Eurozone and global financial crisis on South Africa. Cape town convention center (pp. 123-150). Cape Town: South African Reserve Bank.

Kwiatkowski, D., Phillips, P. C. B., Schmidt, P. \& Shin, Y. (1992). Testing the null hypothesis of stationarity against the alternative of a unit root. Journal of Econometrics, 159-178.

MAG. (2015). Assessing the macroeconomic impact of the transition to stronger capital and liquidity requirements. New York: Macroeconomic Assessment Group.

Mboweni, T. T. (2010). The implications of the global financial crisis in South Africa and the policy responses. Pretoria: South African Reserve Bank.

Meh, C. A. \& Moran, K. (2010). The role of bank capital in the propagation of shocks. Journal of economic dynamics and control, 555-576.

Peersman, G. \& Straub, R. (2006). Putting the New Keynesian model to test. Journal of International Finance, 135-143.

Pesaran, H. M. \& Smith, R. (1995). Estimating long-run relationships from dynamic heterogeneous panels. Journal of Econometrics, 79-113.

SARB. (2015). Annual Report. Johannesburg: South African Reserve Bank.

SARB. (2016). Annual report. South African Reserve Bank (pp. 123-135). Cape Town: South African Reserve Bank.

Tabak, M. \& Souto, T. (2010). Financial intermediation costs in low-income countries. Journal of International Finance, 140-155.

Van Roy, P. (2005, August 15). The impact of the 1988 Basel Accord on banks capital ratios and credit risktaking. International Banking Regulations, pp. 125-142.

Vanhoose, D. (2007). Theories of banking behaviour under capital regulation. Journal of Banking and Finance, 3680-3697.

Were, M. \& Wambua, J. (2014). What factors drive interest rate spreads of commercial banks? Empirical evidence from Kenya. Journal of banking and finance, 73-82.

Wickens, M. R. (1996). Interpreting cointegrating vectors and common stochastic trends. Journal of Econometrics, 235-257.

Woodford, M. (2012). Methods of policy accommodation at the interest rate lower bound. In M. Woodford, Macroprudentialism (pp. 145-160). New York: Oxford University Press. 